are used to determine the bending, tension, compression, shear and impact strength of plywood. The results obtained from tests on twenty-five different species of 3/16-in. three-plywood are included. A comparison of the strength properties of the various species is shown in block diagram form with the names of the twenty-five plywoods used. The results indicate that Canadian birch plywood possesses the greatest shear strength. Those experimented with were species of the genera Terminalia, Catostemma, Berlinia, Betula, Bursera, Octomeles, Daniellia, Cistanthera, Aucoumea, Ocotea, Khaya, Afrormosia, Protium, Sterculia, Mimusops, Mora, Tarrietia, Araucaria, Calophyllum, Pterygota, Gonystylus, Shorea, Parashorea, Sterculia v, rhinopetala and S. oblonga. It is stated that Part 2 of the bulletin will cover investigations on the effect of the shape and thickness of the veneers used in the construction of plywood upon its strength and it will be issued separately when results are available. The object of the whole investigation is to obtain strength data which will allow the comparison of plywoods made from various species of timber and the derivation of working stresses.

\section{Radioactive Tracers in Plant Nutrition}

R. P. Martin and R. Scott Russell have reported on the effect of radiation from phosphorus-32 on the growth and phosphate utilization of barley seedlings maintained in water culture $(J . E x p$. Bot., 5, 91; 1954). Concentrations of carrier phosphate ranging from less than 0.01 to 31 p.p.m. phosphorus were employed for varying periods. It was observed that between experiments there were wide variations in the nature and extent of the effects of radiation. An increase in the proportion of the absorbed phosphate translocated to the shoots, and the reduction of root weight, were the most consistent symptoms. While severe injury was characterized by a reduction in both growth and phosphate absorption, intermediate levels of phosphorus-32 on occasion caused increases in dry weight, in nutrient absorption, and in the development of lateral meristems. 'The reduced metabolic activity of root meristems is considered to be the primary effect in the syndrome of radiation injury. Although injury is due to the accumulation of phosphorus-32 in meristematic regions, no close correlation could be shown between its extent and the level of radiation received by the meristems. The inaccuracy of present methods for estimating the levels of radiation to which tissues are exposed has complicated the investigations of this subject. It appears, however, that the injurious level of radiation may vary from less than 10 to more than 40 rep. per day when the treatment period is 5-7 days. If active accumulation of phosphate occurs, the meristems of plant roots may receive this dosage when treated with more than $5 \mu \mathrm{c}$. of phosphorus-32 per litre for periods of six days. The authors discuss the extent to which the effects of radiation may complicate the interpretation of the results of plant physiological investigations.

Forestry in Nigeria: Annual Report for 1951-52

THE political and administrative changes which are taking place in some of the Colonies of the British Commonwealth are having their inevitable repercussion on the Forest Departments. Nigeria is now divided into three largely self-governing regions, termed Northern, Eastern and Western, which are united under one Central House of Representatives and a Council of Ministers. Thus, as is indicated in the annual report of the Forest Department for 1951-52 (pp. 38. Lagos: Government Printer; London : Crown Agents for the Colonies; $1953 ; 9 d$. net), the Department becomes a regional matter and, accordingly, it, though nominally still a unit, has been split into three more or less independent sections under a Chief Conservator. At the centre, as the adviser of the central government, is an Inspector-General whose functions are to see that the Regions are carrying out a central policy, to act as a co-ordinator between the Regions, to advise on distribution of staff, for whose discipline, promotion and so forth he is largely responsible and to be the general representative of Nigeria in forestry matters. The present report, written by the Inspector-General, states: "All powers under existing legislation, save for such central concerns as control of exports or the appointment of staff, have been transferred to the Regions". This removal of function from the centre applies to the policy, too, and where the ultimate decision regarding dereservation of any parts of the forest estates was specifically vested in the Governor, it now lies regionally with the Lieutenant-Governor concerned. On the subject of the size of the forest estate, it is pointed out that the "overall percentage falls far short of what the optimum of a Forest Estate in this or any other country should be". The report deals with the forest administration as a whole-the main features of the regional reports. The Forest Research Branch, as also the Forest School, remains under the Inspector-General ; the work of the former is becoming increasingly important.

\section{Bird Preservation}

THE report for 1953 of the International Committee for Bird Preservation directs attention to the fact that the Committee has now been in existence for thirty-one years and gives many examples of the ready co-operation existing between the various national sections; the success of the international conference on oil pollution of the sea, held in London in October last year, is a striking example. In addition to the urgent question of oil pollution the British section has also been engaged in work in connexion with new legislation for the protection of birds. Early in the year a number of complaints were forwarded to the British section concerning a measure it was proposed to bring into force in Cyprus under which the nse of bird-lime for catching birds would be permitted. The British section pointed out to the Secretary of State for the Colonies that the practice had been condemned by almost every country in Europe, and its prohibition was contained in the Intermational Convention for the Protection of Birds, which was signed ad referendum in Paris in May 1950 by representatives of twelve different countries. The matter was settled satisfactorily.

During the year the Scottish Ornithologists' Club undertook to make an investigation into the effect of herring gulls on other species, and appointed Dr. J. A. Gibson to take charge of this work. This is part of a scheme which was initiated at a meeting in Sweden in 1950 when it was decided to make a yearly survey of the numbers and details of herring gull colonies in the countries bordering the North Sea, with observations of the effects of these birds on other species, and records of the measures taken to control their numbers and the results obtained. Detailed records are being kept in Denmark, Germany 